\title{
アミノポリカルボン酸型キレート剤についで
}

\author{
中部キレスト株式会社 研究部 古川 正 法
}

\section{Application of Aminopolycarboxylic Acid Chelating Agents}

\section{Masanori Furukawa}

R\&D Department Chubu Chelest Co., Ltd.

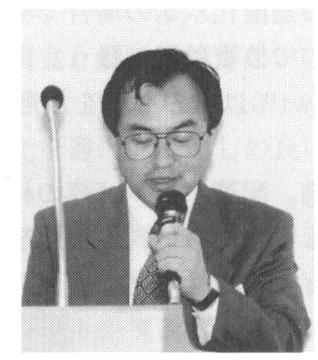

Chelating agents form highly stable complexes with metal ions. They are applied to various processes of many industries for preventing troubles by metals. Aminopolycarboxylic acid type chelating agents such as EDTA and DTPA have largest quantities of products compared with other types of commercial chelating agents.

This paper explains introductory chemistry of chelating agents and reports the usege in pulp industry. Additionaly, new types of biodegradable chelating agents are presented.

分類 : $\mathrm{K}_{3}$ 酸素漂白, $\mathrm{J}_{5}$ 洗浄 - 濃縮, $\mathrm{W}_{0}$ その他

\section{1.はじめに}

アミノポリカルボン酸は, 複数のアミノ基とカルボ キシル基を持った化合物の総称である。窒素とカルボ
ン酸イオンが金属イオンと強く結合して，アミノポリ カルボン酸と金属イオンモル比が 1 対 1 のキレート化 合物を生成する（図 1)。この反応は，金属の純度分 析に使用されているほどの定量性がある。今日, アミ

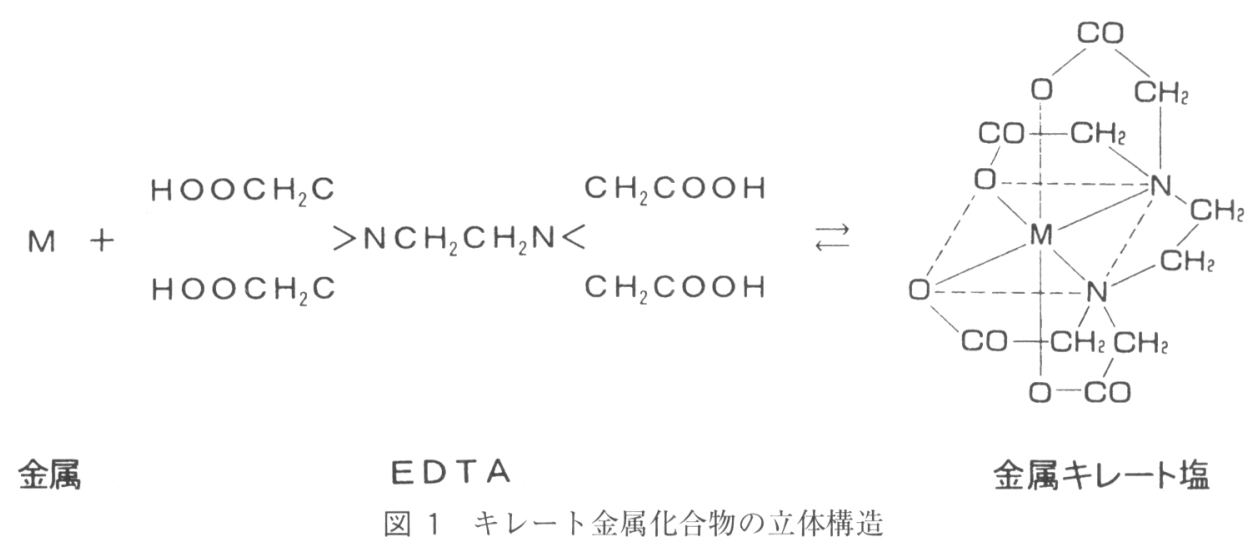

*「パルプ化工程使用薬品セミナー」講演 
ノポリカルボン酸型キレート殽は, 金属イオンが原因 で発生する種々のトラブルを防止し製品を安定化する 目的で，多くの産業分野で使用されている。

紙パルプ工業でも，木材に含有されている金属の溶出, 用水や使用薬品中よりの持ち込み, 装置の磨耗・腐食 等に起因する金属が, 漂白効率の低下・紙の色戻り・ ピッチトラブル・装置にスケールの付着等の原因とさ れています。GPの過酸化水素漂白工程では古くから 使用されてきたが, 近年の環境規制の強化から KPで 酸素系漂白が注目されるようになり，KPでのキレー ト剂の使用が増加している。

図 2 に, S 46 年より H 9 年 7 月までのキレート剂 の紙パルプ関連特許の出願数を示す。近年, キレート 剂に対する関心が強くなっていることがわかる。

\section{2. キレート剂の歴史と用途}

\section{1 キレート剂の歴史}

1937 年, ドイツの I. G. 染料工業会社で EDTA（エ チレンジアミン四酢酸) の特許が初めて出願され, EDTA とNTA（ニトリロ三酢酸）のナトリウム塩が 緎維工業の硬水軟化剂として発売された。以来, キレ 一ト剂の金属マスキング作用, イオン緩衝作用, 酸化 還元作用等を利用して種々の産業で利用されてきた。 特に, 羊毛や綿の精錬・漂白・染色関連では, 長い使 用実績がある。用途に合わせて，キレート能力をもつ 化合物が多数合成されたが, 依然として EDTA と
NTA はアミノポリカルボン酸系キレート剤としては 高い生産量がある。これらの化合物は，【コンプレキ サン型配位子 (Complexane type ligand) ] [Sequestering Agent][Chelating Agent] と呼ばれている。国内 では, [金属イオン封鎖剂], [キレート化剂 $]$ といわ れてきたが, 現在では [キレート郕] が通称になって いる。[Chelate］とは，金属の周囲に配位したカルボ ン酸の形がワシのつめやカニのハサミで物をつかむ様 子に似ていることから, ギリシャ語の “ $\chi \eta \lambda \eta ”$ (Chele=ワシのつめ) または“Kelos”（CrabScissors =カニのハサミ）からきた用語と言われている。

\section{2 キレート剂の用途と生産量}

キレート剂には, 無機系（縮合リン酸塩, ゼオライ ト）と有機系（アミノポリカルボン酸塩, 有機酸塩, ポリカルボン酸塩, ホスホン酸塩）があるが, 工業的 には, キレート能力の高い有機系のアミノポリカルボ ン酸塩が一般に使用されている。用途は, 纎維（精錬 - 漂白・染色助剂), 石嗝・洗剂（金属石畧㑒の沈殿防 止, 酸化防止, 洗浄性改良), 金属表面処理 (無電解 メッキ, 脱脂, 脱錆, スケール溶解), 紙・パルプ(前 洗浄・漂白助剂, スケールの溶解), ゴム・高分子(酸 化防止, 金属触媒除去, 重合触媒助剂), 食品 (変色 ·沈殿 - 酸化防止), 農業・水産 (金属塩が微量要素 補給用), 化粧品 (変色・沈殿・酸化防止), 写真 (漂 白, 洗浄), 医薬品 (酸化防止, 重金属の排泄・解毒), 分析化学 (金属の定量), 環境処理 (脱硫・脱硝助剂),

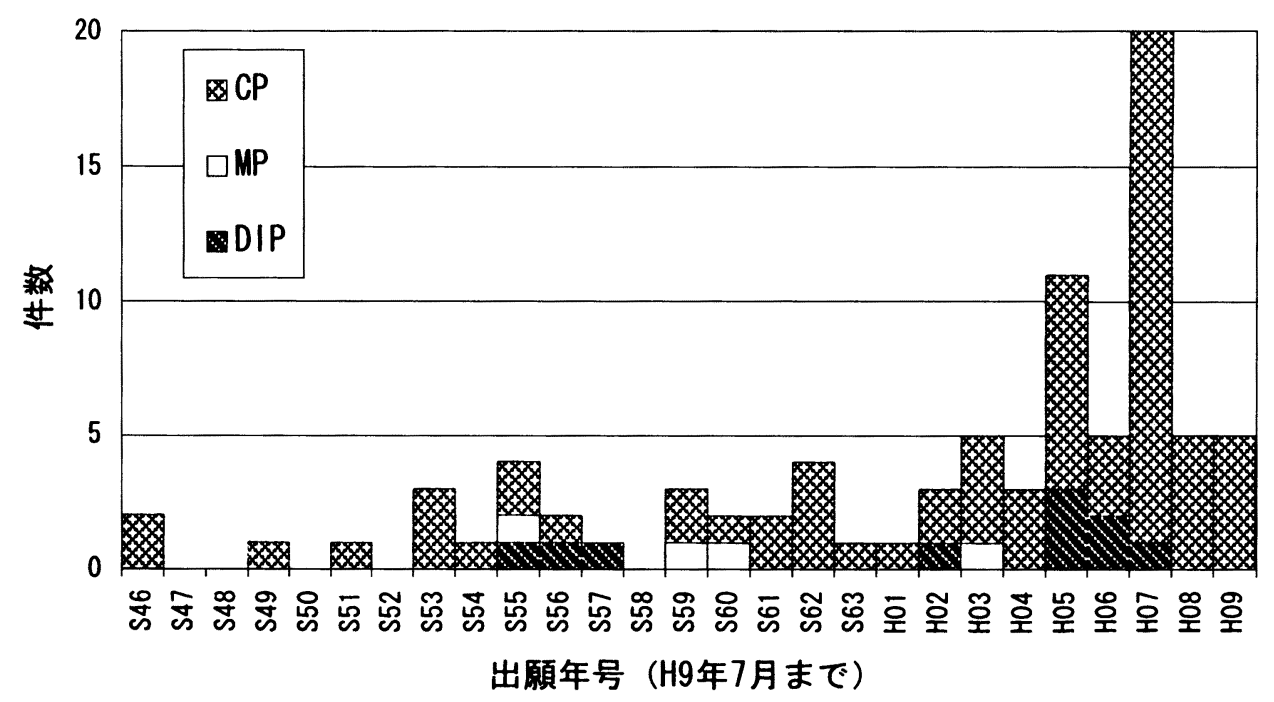

図 2 キレート剂の紙パルプ関連特許

検索条件 S1：(製紙? ) * (キレート?+EDTA + DTPA $)=(18,994$ 件 * 9, 670件 $)=130$ 件 $\mathrm{S} 2:$ (故紙) $*($ キレート?+EDTA + DTPA $)=(2,246$ 件 $* 9,670$ 件 $)=13$ 件 $\mathrm{S} 3: \mathrm{S} 1+\mathrm{S} 2=132$ 件 
皮革 (なめしの促進), 水処理（軟水化, 洗浄, 清缶), 治金（分離，精製）等で，金属が原因のトラブルの回 避に使用されている。

アミノポリカルボン酸塩のなかでは, EDTAの生 産量が最も多く, 生産量は年間約 7,000 トン（酸固形 換算）と推定される。酸は水に溶けにくいために, 2 $\mathrm{Na}, 3 \mathrm{Na}, 4 \mathrm{Na}$ 塩結晶, さらに溶解度を上げるため に $2 \mathrm{~K}, 3 \mathrm{~K}, 4 \mathrm{~K}$ 塩の結晶, 灰分を嫌う用途には $2 \mathrm{NH}$ 4 塩の結晶が市販されている。これらの塩は, アルカ リ量が多くなるほど $\mathrm{pH}$ が上がるので, 使用目的 $\mathrm{pH}$ により選択される。用途の $40 \%$ は石喃・洗剤向けで, 硬度成分と洗剤が反応して生成する金属石鹷沈殿の防 止に使用されたり，製品の酸化による劣化防止の目的 で使用されている。紙パルプ工業むけ用途は約 $3 \%$ で，スケール除去や漂白安定敦に使用されている。

DTPA（ジエチレントリアミン五酢酸）は，EDTA と比較して酸化に対する耐性が良くキレート生成能力 もやや高いため, 主にパルプの漂白向けに使用されて いる。DTPA は酸の結晶しか得ることができないの で， $\mathrm{Na}, \mathrm{K}, \mathrm{NH}_{4}$ 塩は液体として市販されている。 年間の生産量は年間約 2,000 トン (5 Na 塩 $40 \%$ 換算) である。写真向けや繊維むけにも，少量の需要がある。

NTA はキレート能力がEDTA より劣るものの, 硬度成分のマスキング・スケール溶解用途には問題な く使用が可能である。EDTA（酸：M.W.292）に比 べて分子量が低いNTA（酸：M.W.191）は，単位重 量あたりのキレートできる金属量が EDTAの 1.5 倍 になり，コスト優位性がある。NTA は酸， $2 \mathrm{Na}, 3 \mathrm{Na}$ 塩の結晶を得ることができる。生産量は年間約 1,300 トン (酸固形換算) と推定される。

\section{3. キレート反応の説明}

\section{1 キレート剤の配位子数}

無機金属塩はイオン結合をしており，水溶液中では, 金属プラスイオンと無機マイナスイオンに解離する。 キレート剤と金属イオンとの結合は配位結合で，イオ ン結合に比べて強く結合する性質がある。O (酸素), $\mathrm{N}$ (窒素), $\mathrm{S}$ (硫黄)， $\mathrm{P}$ (リン) 元素が金属イオンに 配位結合する能力（電子供与体）をもつので，これら の元素を金属に配位しやすいように化合物に組み込む と，様々のキレート剂を合成することができる。

1 つの分子中に 1 つの配位結合をする部分（配位 子：ligand）を持つものを 1 座配位子 [例えば $\mathrm{NH}_{3}$ （ア ンモニア)］という。 $2,3,4, \cdots$ 個の配位子を持つもの を多座配位子（例えば，EDTAは 6 座配位子，DTPA は 8 座配位子）と呼ぶ。多座配位子が金属と結合する と，中心金属イオンが配位子に包み込まれるような形 となり，金属イオン本来の性質が大きく変化します。 1 座配位子と区別して, 多座配位子を一般にキレート 剂[chelating agent]と呼ぶ（図 3)。

\section{2 金属の配位数}

金属は，金属の種類により配位結合する数（配位数 または副原子価）が決まっており，常にその配位数を 満たすように他の配位子と結合しょうとする傾向があ る。1 分子の金属キレート化合物 [metal chelate compound]は，副原子価を満たすように配位子と配位結 合し，さらに，主原子価（普通の原子価：イオンの電 荷）を満たすイオンとイオン結合をしている（表 1)。

アミノポリカルボン酸系のキレート剤は 1 分子内に 多くの配位子を持っているため, 配位数の多い金属と でも 1 モル対 1 モルの比で安定なキレート化合物を生
NTA (ニトリロ三酢酸)<smiles>O=C(O)CN(CC(=O)O)CC(=O)O</smiles>

EDTA(エチレンジアミン四酢酸)

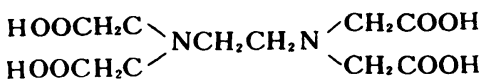

HEDTA（ヒドロキシエチルエチレンジアミン三酢酸）<smiles>O=C(O)CN(CCO)CCN(CCN(CCO)CC(=O)O)CC(=O)O</smiles>

DTPA（ジエチレントリアミン五酢酸）

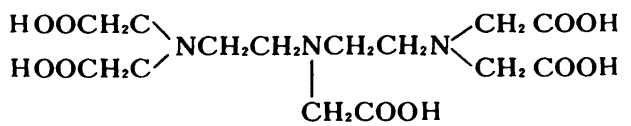

TTHA（トリエチレンテトラミン六酢酸）<smiles>O=C(O)CC(CNCCN(CCOO)CCOO)NCCN(CC(=O)O)CC(=O)O</smiles>

図 3 主なアミノポリカルボン酸系キレート剤の化学式 
表 1 主なキレート刻の配位子数と金属イオンと配位数

\begin{tabular}{|c|c|c|}
\hline キレート剤 & $\begin{array}{l}\text { 配 位 数 } \\
\text { 配位子数 }\end{array}$ & 金属イオン \\
\hline グリシン & 2 & $\mathrm{Cu}^{+} \mathrm{Ag}^{+} \mathrm{Hg}^{+} \mathrm{Hg}^{2+}$ \\
\hline NTA & 4 & $\begin{array}{llllllll}\mathrm{Li}^{+} & \mathrm{Be}^{+} & \mathrm{B}^{3+} & \mathrm{Zn}^{2+} & \mathrm{Cd}^{2+} & \mathrm{Hg}^{2+} & \mathrm{Ai}^{3+} & \mathrm{Co}^{2+} \\
\mathrm{Ni}^{2+} & \mathrm{Cu}^{2+} & \mathrm{Ag}^{2+} & \mathrm{Au}^{3+} & \mathrm{Pd}^{2+} & \mathrm{Pt}^{2+} & \mathrm{Mg}^{2+}\end{array}$ \\
\hline $\begin{array}{c}\text { EDTA } \\
\text { СyDTA }\end{array}$ & 6 & $\begin{array}{lllllllll}\mathrm{Ca}^{2+} & \mathrm{Sr}^{2+} & \mathrm{Ba}^{2+} & \mathrm{Ti}^{4+} & \mathrm{V}^{3+} & \mathrm{V}^{5+} & \mathrm{Cr}^{3+} & \mathrm{Mn}^{2+} \\
\mathrm{Mn}^{3+} & \mathrm{Fe}^{2+} & \mathrm{Fe}^{3+} & \mathrm{Co}^{2+} & \mathrm{Pd}^{4+} & \mathrm{Pt}^{4+} & \mathrm{Cd}^{2+} & \mathrm{Al}^{3+} \\
\mathrm{Sc}^{3+} & \mathrm{Y}^{3+} & \mathrm{Si}^{4+} & \mathrm{Sn}^{2+} & \mathrm{Sn}^{4+} & \mathrm{Pd}^{2+} & \mathrm{Pb}^{4+} & \mathrm{Ru}^{3+} \\
\mathrm{Rh}^{3+} & \mathrm{Os}^{3+} & \mathrm{Ir}^{3+} & \text { ランタニド } & & \end{array}$ \\
\hline DTPA & 8 & $\mathrm{Zr}^{4+} \quad \mathrm{Hf}^{4+} \quad \mathrm{Mo}^{4+} \quad \mathrm{W}^{4+} \quad \mathrm{U}^{4+} \quad$ アクチニド \\
\hline
\end{tabular}

成する（図 4)。

\section{3 キレート剤の安定度定数}

キレート金属化合物の生成反応の完結度は, 金属の配 位され易さとキレート剤の配位能力（配位子の配位能 力や，無理のない立体構造をとれるか）の組み合わせ て決まる。一般に金属イオンとキレート剤イオンの平 衡反応は次の式で示される。

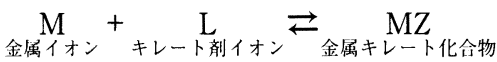

$$
\begin{aligned}
& \mathrm{K}=\frac{[\mathrm{ML}]}{[\mathrm{M}] \times[\mathbf{L}]}
\end{aligned}
$$

平衡定数（K）の值は金属キレート化合物の安定度 をはかる目安であり,“キレート安定度定数”または “キレート生成定数”と呼ばれている。キレート化反 応は完結度の高い反応で $\mathrm{K}$ の值は非常に大きいため, 通常はその対数值 $[\log (\mathrm{K})]$ で表す。

紙パルプ工業で悪影響のある $\mathrm{Fe}^{3+}, \mathrm{Cu}^{2+}, \mathrm{Mn}^{2+}$ イ オンの安定度定数は極めて高いので, $\mathrm{Ca}^{2+}, \mathrm{Mg}^{2+}$ イ オンが多量にある系でも，添加したキレート剤は確実 に $\mathrm{Fe}^{3+}, \mathrm{Cu}^{2+}, \mathrm{Mn}^{2+}$ イオンと反応する（表 2)。また， キレート率と金属が混合している系では，キレート能 力の高いキレート䇕とキレートされやすい金属の組み 合わせからなるキレート金属塩が生成し，以下強いも の順の組み合わせでキレート金属塩ができる。

アミノポリカルボン酸系キレート剤は弱い有機酸な ので $\mathrm{pH}$ が低下すると解離しているイオン濃度が少な くなり，同じ濃度のキレート剂を添加しても金属キレ 一ト化合物が生成する量は少なくなる。通常は, $[\mathrm{L}$ ： キレート剤イオン濃度 $]$ の代わりに $\left[\mathrm{L}^{\prime}\right.$ : 金属と結 合していないキレート剤の全濃度ををもちいて計算し た平衡定数（K’）を使用するほうが便利なので，こ の值を [みかけの安定度定数］と称して常用されてい
る(表 3)。

\section{4 キレート剤の沈殿防止効果}

図 5 に，金属水酸化物の溶解度と $\mathrm{pH}$ の関係を示す。 金属水酸化物の溶解度は極めて低いので，プロセス中 で $\mathrm{pH}$ が上昇する個所で水酸化物の沈殿が生成して, スケールの発生や製品の污染の原因になる。また，金 属ケイ酸塩も溶解度が低いのでスケールトラブルの原 因になる。

金属水酸化物沈殿の生成反応は, 金属に $\mathrm{OH}^{-}$イ才 ンが配位する反応である。安定度定数の高いキレート 片を共存させると, $\mathrm{OH}^{-}$イオンより先にキレート剤 が配位してキレート金属塩ができる。キレート金属塩 は溶解度が高いので（通常 $20 \sim 40 \%$ ），水酸化物の沈 殿を防止することができる。

溶解度の低い $\mathrm{Fe}^{3+}$ イオンの場合で, 沈殿防止効果 を試算した結果を以下に示す。

初期 $\mathrm{Fe}^{3+}$ イオン濃度 (M.W.55.8) : $5 \mathrm{ppm}$ $8.96 \times 10^{-5} \mathrm{~mol} / \mathrm{L}$

初期 DTPA $5 \mathrm{Na}$ 濃度 (M.W. 503) : $150 \mathrm{ppm}$ $29.8 \times 10^{-5} \mathrm{~mol} / \mathrm{L}$

$\mathrm{pH} 4.0$ でのみかけの安定度定数 $10^{19.3}$

遊離の $\mathrm{Fe}^{3+}$ イオン濃度を $\left[\mathrm{Fe}^{3+}\right]$ とした平衡式 $\left[8.96 \times 10^{-5} /\left(\left[\mathrm{Fe}^{3+}\right] \times 20.8 \times 10^{-5}\right)\right]=10^{19.3}$ 計算した遊離の $\mathrm{Fe}^{3+}$ イオン濃度

$$
\begin{aligned}
{\left[\mathrm{Fe}^{3+}\right] } & =2.16 \times 10^{-20} \mathrm{~mol} / \mathrm{L} \\
& =1.20 \times 10^{-15} \mathrm{ppm}
\end{aligned}
$$

$\mathrm{pH} 4.0$ での水酸化鉄の溶解度

$\mathrm{Fe}^{3+}$ イオン濃度として $0.05 \mathrm{ppm}$

$5 \mathrm{ppm}$ の $\mathrm{Fe}^{3+}$ イオン濃度で $\mathrm{pH} 4.0$ では水酸化鉄の 沈殿が発生するが，キレート剤を添加することにより 遊離の $\mathrm{Fe}^{3+}$ イオン濃度が低くなるので沈殿は発生し 
(NTA)

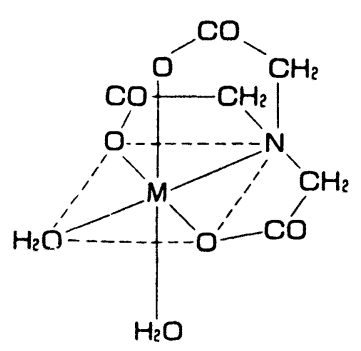

配位数6の金属イオンに対して

\section{(EDTA)}

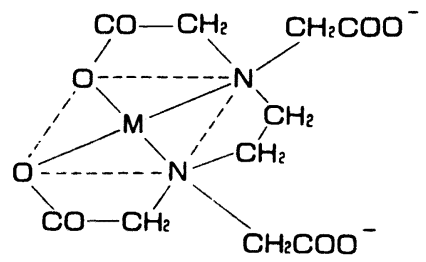

配位数4の金属イオンに対して

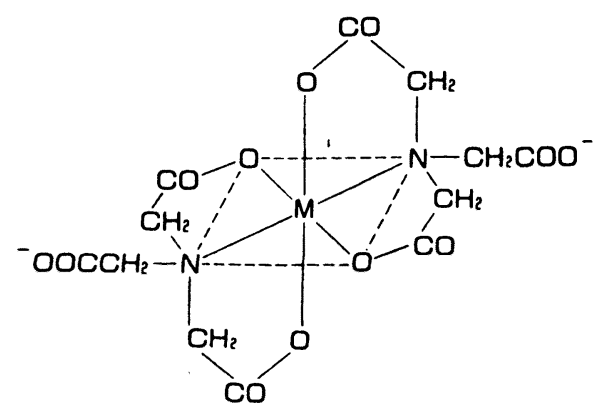

1:2の結合の場合

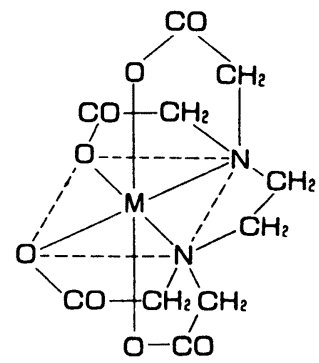

配位数6の金属イオンに対して

\section{(DTPA)}

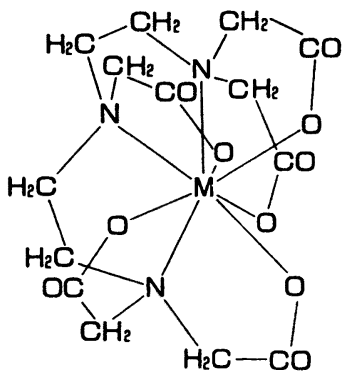

配位数8の金属イオンに対して

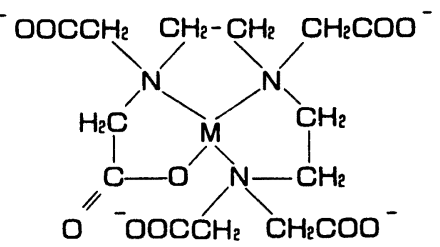

配位数4の金属イオンに対して

図 4 金属キレート化合物の立体構造 
表 2 キレート剂の安定度定数の比較 $[\log (\mathrm{K})]$

\begin{tabular}{c|c|c|c|c}
\hline 金属イオン & NTA & HEDTA & EDTA & DTPA \\
\hline $\mathrm{Fe}^{3+}$ & 15.9 & 19.8 & 25.1 & 28.6 \\
\hline $\mathrm{Cu}^{2+}$ & 13.2 & 17.6 & 18.8 & 21.1 \\
\hline $\mathrm{Mn}^{2+}$ & 7.4 & 10.7 & 14.0 & 15.5 \\
\hline $\mathrm{Ca}^{2+}$ & 6.6 & 8.5 & 10.9 & 10.7 \\
\hline $\mathrm{Mg}^{2+}$ & 5.4 & 7.0 & 8.7 & 9.0 \\
\hline
\end{tabular}

表 $3 \mathrm{Fe}^{3+}$ イオンのみかけの安定度定数 $\left[\log \left(\mathrm{K}^{\prime}\right)\right]$

\begin{tabular}{l|c|c|c|c|c|c|c|c|c|c|c|c}
\hline \multirow{2}{*}{ 配位子 } & \multicolumn{10}{|c}{$\mathrm{pH}$} \\
\cline { 2 - 14 } & 3 & 4 & 5 & 6 & 7 & 8 & 9 & 10 & 11 & 12 & 13 & 14 \\
\hline HEDTA & 10.3 & 12.4 & 14.2 & 15.7 & 16.8 & 17.8 & 18.8 & 19.5 & 19.8 & 19.8 & 19.8 & 19.8 \\
\hline EDTA & 14.5 & 16.7 & 18.7 & 20.5 & 21.8 & 22.9 & 23.8 & 24.7 & 25.0 & 25.1 & 25.1 & 25.1 \\
\hline DTPA & 13.9 & 16.9 & 19.3 & 21.4 & 23.4 & 25.3 & 26.9 & 27.9 & 28.5 & 28.6 & 28.6 & 28.6 \\
\hline
\end{tabular}

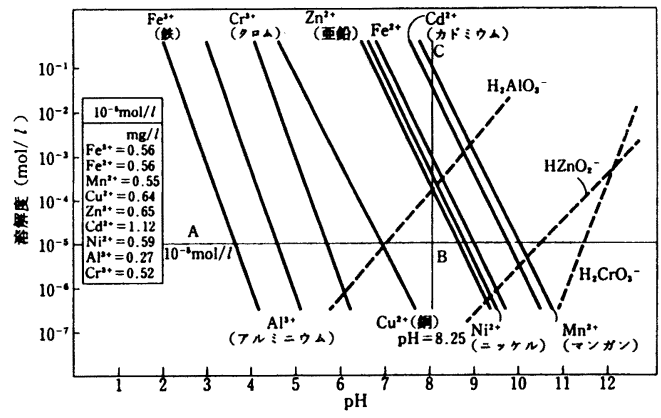

図 5 金属水酸化物の溶解度と $\mathrm{pH}$ の関係（溶解度積 より計算)

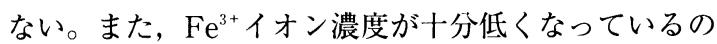
で, $\mathrm{Fe}^{3+}$ イオンが触媒になっているさまざまな反応も 防止することが可能である。

逆に，発生した水酸化物の沈殿の溶解も可能である が, 水酸化物は発生してから時間が経過すると再溶解 が難くなるので，あらかじめキレート剤を添加してお く方が効果的である。

$\mathrm{pH}$ が高くなると $\mathrm{OH}^{-}$イオン濃度が高くなり, 配位 しているキレート剤が $\mathrm{OH}^{-}$イオンに置き換わるので, 水酸化物の沈殿が発生する。キレート剤 $[1 \mathrm{~g}]$ がキ レートして溶解する金属量を $[\mathrm{mg}]$ 数で表示した值を [キレート価 (Chelation Value : 略称C.V.) ] と称す る。一般に, Ca イオンの場合は水の硬度の表示と整

[ …..... EDTA4Na (M.W.380) 、 CaイオンのC. V.

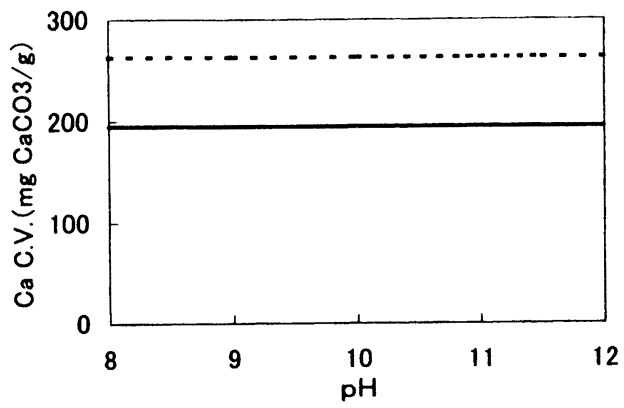

DTPA5Na(M.W.503)]

$\mathrm{Fe}^{3-イ オ ン の C . ~ V . ~}$

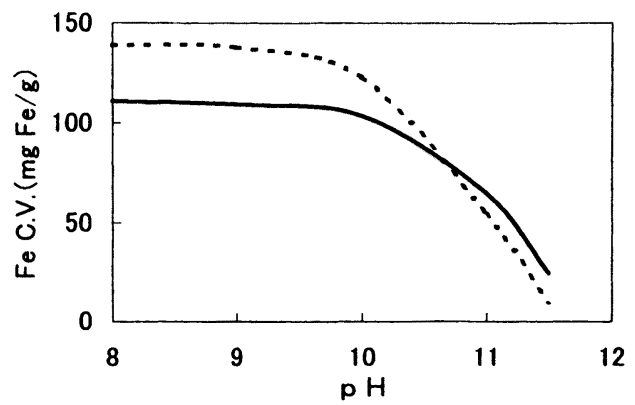

図 6 高 $\mathrm{pH}$ 領域での C.V. 
合性を持たせるために, $\mathrm{CaCO}_{3}$ (M.W. 100) 換算で表 示する。Ca イオンは水酸化物の溶解度が比較的高い ので, C.V.は高 $\mathrm{pH}$ でも低下しないが, $\mathrm{Fe}^{3+}$ イオン の場合は $\mathrm{pH} 11$ 以上でキレート骺の沈殿防止効果が 急激に弱くなる。 $\mathrm{Mn}^{2+}$ も $\mathrm{pH} 12$ 以上で同様の傾向が あり，いずれも漂白工程での“アルカリ焼け”の原因 と考えられる(図6)。

\section{EDTA, DTPA の物性}

\section{1 物 性}

アミノポリカルボン酸系キレート剂は, 遊離酸タイ プから $\mathrm{Na}, \mathrm{K}, \mathrm{NH} 4$ 塩まで市販されている。EDTA の $\mathrm{Na}$ 塩は $2,3,4$,ナトリウム塩の結晶が得られてい る。DTPA は遊離酸の結晶は作ることができるが, アルカリ塩結晶は作ることができないので, DTPA のアルカリ塩は水溶液で市販されている（表 4)。
遊離酸の溶解度は低く, アルカリで $\mathrm{pH}$ を上げると 溶解度が增加する。通常の用途では添加量が低いので, $\mathrm{pH}$ の低下で遊離酸の結晶が析出することはない。 $\mathrm{pH}$ の低い領域で溶解度の高いキレート剂としては, HEDTA (Hydroxyethyl Ethylene Diamine Triacetic Acid）があり， $5.5 \%\left(25^{\circ} \mathrm{C} ）\right.$ の溶解度がある。

空気中で高温加熱したり着火源があると燃焼するが,

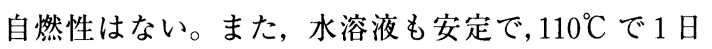
保持しても, 加水分解量は分析誤差以内である。酸や アルカリに対しても安定だが, 高濃度の酸化剂 $\left(\mathrm{CrO}_{3}\right.$, $\left.\mathrm{KMnO}_{4}, \mathrm{H}_{2} \mathrm{O}_{2}\right)$ では分解され, 低級なアミンとホル ムアルデヒドを生成する。EDTA は過酸化水素の安 定剤としては不むきであるが, DTPA は安定剤とし て優れた効果を示す。

\section{2 取り扱い注意事項}

EDTA, DTPA は化粧品原料基準や食品添加物公

表 4 EDTA·DTPA の物性表

\begin{tabular}{|c|c|c|c|c|c|}
\hline & \multicolumn{3}{|c|}{ EDTA } & \multicolumn{2}{|c|}{ DTPA } \\
\hline & $\mathrm{EDTA} \cdot 4 \mathrm{H}$ & $\mathrm{EDTA} \cdot 2 \mathrm{Na} \cdot 2 \mathrm{H}$ & $\mathrm{EDTA} \cdot 4 \mathrm{Na}$ & DTPA. $5 \mathrm{H}$ & DTPA $5 \mathrm{Na}$ \\
\hline 結晶水 & ナシ & $2 \mathrm{H}_{2} \mathrm{O}$ & $4 \mathrm{H}_{2} \mathrm{O}$ & ナシ & $40 \%$ 水溶液 \\
\hline 分子量 & 292 & 372 & 452 & 393 & 503 \\
\hline 示性式 & $\mathrm{C}_{10} \mathrm{H}_{16} \mathrm{~N}_{2} \mathrm{O}_{8}$ & $\begin{array}{c}\mathrm{C}_{10} \mathrm{H}_{14} \mathrm{~N}_{2} \mathrm{O}_{8} \mathrm{Na}_{2} \\
\cdot 2 \mathrm{H}_{2} \mathrm{O}\end{array}$ & $\begin{array}{c}\mathrm{C}_{10} \mathrm{H}_{12} \mathrm{~N}_{2} \mathrm{O}_{8} \mathrm{Na}_{2} \\
\cdot 4 \mathrm{H}_{2} \mathrm{O}\end{array}$ & $\mathrm{C}_{14} \mathrm{H}_{23} \mathrm{~N}_{3} \mathrm{O}_{10}$ & $\mathrm{C}_{14} \mathrm{H}_{18} \mathrm{~N}_{3} \mathrm{O}_{10} \mathrm{Na}_{3}$ \\
\hline 化審法番号 & $2-1263$ & $2-1265$ & $2-1265$ & $2-1273$ & $2-1274$ \\
\hline CAS No & $60-00-4$ & $6381-92-6$ & $13235-36-4$ & $67-43-6$ & $140-01-2$ \\
\hline 外観 & 白色結晶粉末 & 白色結晶粉末 & 白色結晶粉末 & 白色結晶粉末 & 淡黄色液体 \\
\hline $\mathrm{pH}$ & 2.9 & 4.4 & 11.0 & 2.5 & 12.0 \\
\hline C. V. $\left(\mathrm{mgCaCO}_{3} / \mathrm{g}\right)$ & 342 & 268 & 221 & 254 & 80 \\
\hline 融点 $\left({ }^{\circ} \mathrm{C}\right)$ & 245 (分解) & 240 (分解) & 320 (分解) & 220 (分解) & 105 (沸点) \\
\hline 溶解度 $\left(25^{\circ} \mathrm{C}: \%\right)$ & 0.03 & 10.7 & 54 & 0.4 & 結晶化せず \\
\hline その他 & & & 吸湿性 & & \\
\hline $0.1 \%$ 品 $\mathrm{COD}(\mathrm{ppm})$ & 780 & 640 & 740 & & 260 \\
\hline $0.1 \%$ 品BOD $(\mathrm{ppm})$ & 38 & 28 & 33 & & 12 \\
\hline $\mathrm{LD} 50(\mathrm{mg} / \mathrm{kg})$ & $\begin{array}{c}2,000 \\
\text { 経ロラット }\end{array}$ & $\begin{array}{c}2,000 \\
\text { 経ロラット }\end{array}$ & $\begin{array}{c}2,700 \\
\text { 経ロラット }\end{array}$ & $\begin{array}{c}4,919 \\
\text { 経ロラット }\end{array}$ & $\begin{array}{c}390 \\
\text { 腹腔内マウス }\end{array}$ \\
\hline 魚毒性 $(\mathrm{mg} / \mathrm{L})$ & $\begin{array}{c}\text { LC } 50 \\
>500 \mathrm{mg} / \mathrm{L}\end{array}$ & $\begin{array}{c}\mathrm{LC} 50 \\
>500 \mathrm{mg} / \mathrm{L}\end{array}$ & $\begin{array}{c}\text { TLm } 96 \\
100 \sim 1,000 \mathrm{mg} / \mathrm{kg}\end{array}$ & & $\begin{array}{c}\mathrm{LC} 50 \\
1,115 \mathrm{mg} / \mathrm{L}\end{array}$ \\
\hline 化粧品原料基準 & 記載 & 記載 & 記載 & & 記載 \\
\hline 食品添加物公定書 & & 記載 & & & \\
\hline
\end{tabular}


表 5 鉄及び銅の浸漬試験による年間腐食度 $(\mathrm{mm} /$ 年 $)$

キレート剂濃度 $(\mathrm{Na}$ 塩, $2.0 \mathrm{wt} \%)$, クエン酸で $\mathrm{pH}$ 調整, 試験温度 $88^{\circ} \mathrm{C}$

\begin{tabular}{c|c|c|c|c|c|c}
\hline & \multicolumn{3}{|c|}{ 鉄鋼 $(\mathrm{SS}-400)$} & \multicolumn{3}{c}{ タフピッチ銅 $(\mathrm{CL} 100 \mathrm{P})$} \\
\hline $\mathrm{pH}$ & ブランク & $\mathrm{EDTA} \cdot 4 \mathrm{Na}$ & $\mathrm{DTPA} \cdot 5 \mathrm{Na}$ & ブランク & $\mathrm{EDTA} \cdot 4 \mathrm{Na}$ & $\mathrm{DTPA} \cdot 5 \mathrm{Na}$ \\
\hline 7 & 0.060 & 1.023 & 0.928 & 0.047 & 0.048 & 0.046 \\
\hline 10 & 0.041 & 0.193 & 0.138 & 0.060 & 0.038 & 0.051 \\
\hline 13 & 0.000 & 0.000 & 0.000 & 0.044 & 0.005 & 0.008 \\
\hline
\end{tabular}

定書に記載されている物質であるので, 通常の化学薬 品に対するとのと同様の取り扱い注意を払えば安全上 の問題はない。遊離酸やアルカリ塩は粘膜に対して刺 激性があるので, 通常の酸やアルカリに対すると同様 の保護具が必要である。

キレート剤の取り扱い装置材質は, $\mathrm{pH} 1.5 \sim 14$ の 範囲でSUS 304 の使用実績がある。鉄は高アルカリ では耐蝕性があるが, $\mathrm{pH}$ の低い領域では腐食される (表 5)。

\section{5. キレート剂の分析方法}

キレート剤の製品分析では，キレート安定度定数の 高いものは $\mathrm{Zn}$ 標準液と金属指示薬としてエリオクロ ーム・ブラック Tを使用したキレート滴定で, 安定 度定数の低いものは $\mathrm{Cu}$ 標準液と金属指示薬としてム レキサイドを使用したキレート滴定で含量を求めるこ

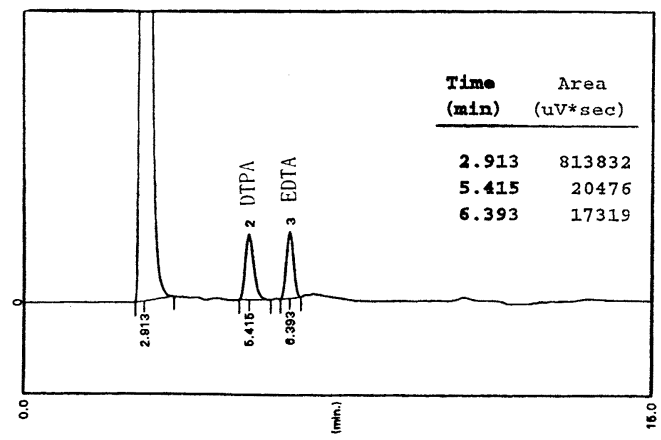

溶離液：ジイソプロピルアミン $/ 2 \mathrm{~m} l, \mathrm{CuSO}_{4} \cdot 5 \mathrm{H}_{2} \mathrm{O} / 0.02 \mathrm{~g}$ を 溶解，リン酸で $\mathrm{pH} 2.5$ に調整し， $1 \mathrm{~L}$ とする。

サンプル前処理：サンプル $/ 10 \mathrm{~g}$ に希釈液（ジイソプロピルアミ ン $/ 20 \mathrm{~m} l, \mathrm{CuSO}_{4} \cdot 5 \mathrm{H}_{2} \mathrm{O} / 20 \mathrm{~g}$ を溶解, リン酸で $\mathrm{pH} 2.5$ に調整 して $1 \mathrm{~L}$ とした液 $) / 10 \mathrm{ml}$ を添加し, リン酸で $\mathrm{pH} 2.5$ に調整し て, 全量を $100 \mathrm{~m} l$ とする。注入量 $/ 20 \mu l$ 。

カラム : GL Sciences/Inertsil ODS-2

溶離液流量 : $0.7 \mathrm{ml} / \mathrm{min}$, オーブン温度 : $35^{\circ} \mathrm{C}$

検出器：UV, 波長 : $254 \mathrm{mn}$

図 7 HPLCによる EDTA・DTPA の分析例 (サンプル：EDTA $4 \mathrm{Na} / 10$ ppm, DTPA $5 \mathrm{Na} / 10$ ppm の混合液)
とができる。

低濃度のキレート剂の分析は, 高速液体クロマトグ ラフィー（HPLC）で分析ができる。溶離液とサンプ ルに Fe または Cuイオンを添加して金属キレートイ オンにして, アミンイオンをぺヤーイオンとすること により ODSカラムで分離することができる。キレー 卜化合物特有の吸収波長がありますので, UV 検出器 で検出する。

\section{6. 紙パルプ製造工程での金属イオンの動向と キレート剂による洗浄効果}

表 6 に材木及びパルプ中の金属イオン含量を, 表 7 に紙パルプ工業で使用されている用水と製造工程中の 処理水の金属イオン量を示す。木材やプロセスの違い, サンプリング個所により, 含量に差がある。紙パルプ 工場で使用している用水の水質はかなり良いものであ るが, パルプより金属が溶出するのと, 処理水のリサ イクルによる蓄積で, 工程中の金属濃度は高くなって いる（表 7）。

パルプ中の金属は，リグニン，フェノール誘導体， 低級有機酸等と弱くキレート結合をしているので, 水 洗で除去しにくくなっている。金属を除くには, キレ 一ト力の強いキレート剤水溶液で洗浄する必要がある (図 8)。

$\mathrm{Ca}, \mathrm{Mg}$ が多量に含有されているパルプでも, Mn,

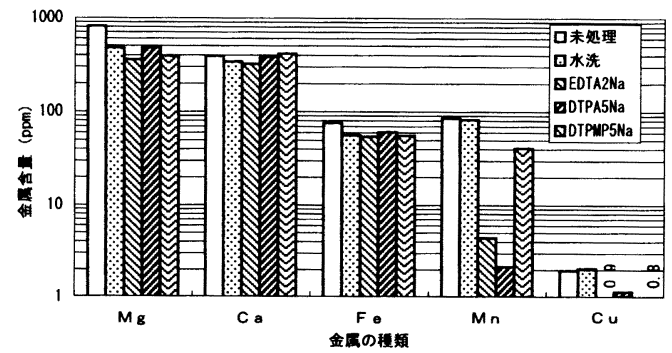

図 8 キレート剤洗浄による GP 中の金属除去 (キレート剂使用量固形換算 $0.3 \%$ 対乾燥パルプ) 


古 川 正 法

表 6 材木及びパルプの金属含有量

\begin{tabular}{l|l|l|l|r|r|r|r}
\hline & \multirow{2}{*}{$\begin{array}{c}\text { 灰分 } \\
\text { (\%) }\end{array}$} & 酸不溶 & \multicolumn{5}{|c}{ 金属含量 $(\mathrm{ppm})$} \\
\cline { 5 - 8 } & & $\mathrm{Mg}$ & $\mathrm{Ca}$ & $\mathrm{Fe}$ & $\mathrm{Mn}$ & $\mathrm{Cu}$ \\
\hline 材木 (Hemlock, western) & & & & & 115 & 106 & 14 \\
\hline 材木 (Hemlock, eastern) & & & & & 20 & 110 & 1 \\
\hline 材木 (Aspen, miwdest) & & & & & 55 & 4 & 5 \\
\hline 材木 (Spruce, eastern) & & & & & 17 & 136 & 1 \\
\hline GP シリンダープレス後 & 3.0 & 2.6 & 670 & 320 & 92 & 94 & 2.3 \\
\hline 漂白後 & & & 1,760 & 120 & 90 & 29 & 0.3 \\
\hline TMP 脱水後 & 3.0 & 1.9 & 440 & 700 & 76 & 5 & 2.1 \\
\hline CGP 脱水後 & 2.4 & 0.02 & 240 & 2,240 & 24 & 18 & 0.8 \\
\hline KP 漂白前 & & & 390 & 610 & 37 & 71 & 0.3 \\
\hline 晒し完了後 & & & 159 & 36 & 14 & 1 & 0.2 \\
\hline
\end{tabular}

（注）材木：J.RogerHart：pulp \& paper, June 1981.p 138 より引用

表 7 紙パルプ製造工程の用水中の金属含有量

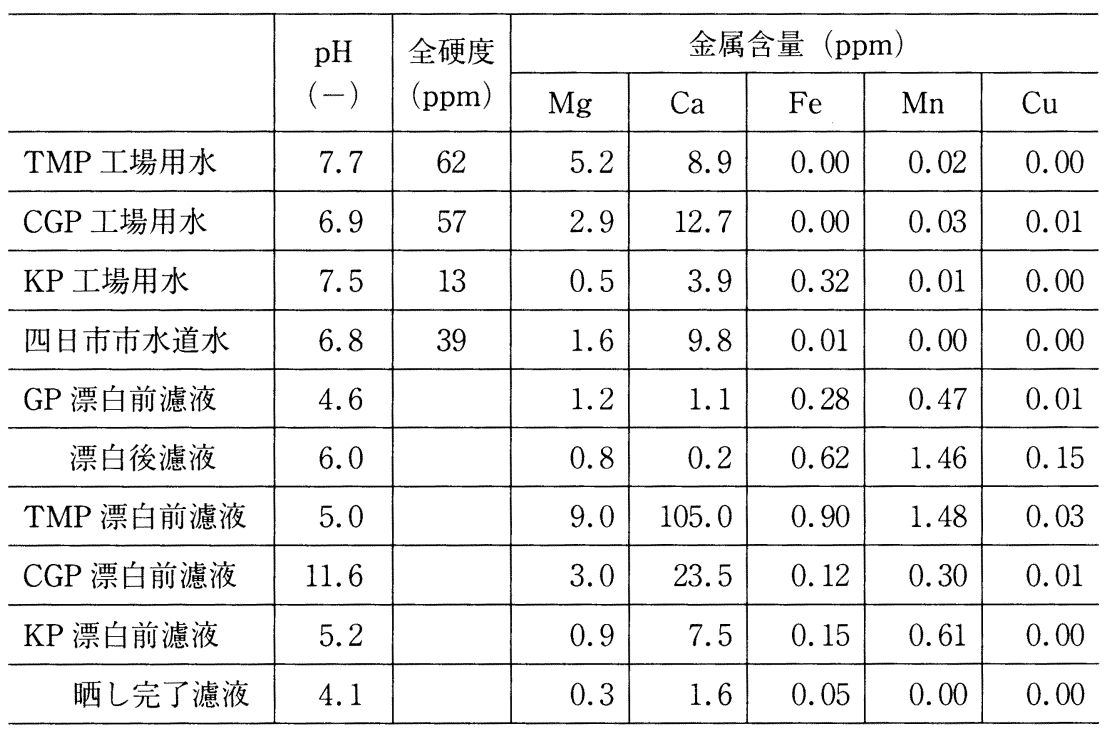

$\mathrm{Cu}$ イオンの洗浄除去効果は顕著である。 $\mathrm{Ca}, \mathrm{Mg}$ に 比べて $\mathrm{Fe}, \mathrm{Mn}, \mathrm{Cu}$ の安定度定数が高いので, 添加 したキレート剤はこれらの金属と優先的にキレート化 して溶解する。生成してから時間が経過した $\mathrm{Fe}(\mathrm{OH})_{3}$ の反応性は悪くなるので, キレート剂での洗浄では除 去することが難しいので, 酸や還元剤との併用が必要 である。

\section{7. キレート剂による過酸化水素の安定化}

\section{1 過酸化水素の分解機構}

アルカリ側での過酸化水素漂白は, $\left[\mathrm{H}_{2} \mathrm{O}_{2}+\mathrm{OH}^{-}\right.$. $\left.\mathrm{OOH}^{-}+\mathrm{H}_{2} \mathrm{O}\right]$ の反応で生じる $\mathrm{OOH}^{-}$(ヒドロパーオ キサイドアニオン）による酸化反応と考えられている。 $\mathrm{OOH}^{-}$を生成するにためには適度なアルカリ性を保持 する必要がある。過度のアルカリ側では, $\mathrm{OOH}^{-}$と過 
酸化水素との反応や重金属の触媒作用により，過酸化 水素の分解が起きて漂白効率が低下する。

$\mathrm{OOH}^{-}$による分解機構

$$
\begin{aligned}
& \mathrm{H}_{2} \mathrm{O}_{2}+\mathrm{OOH}^{-} \rightarrow \mathrm{HO} \cdot+\mathrm{O}_{2}^{-} \cdot+\mathrm{H}_{2} \mathrm{O} \\
& \mathrm{HO} \cdot+\mathrm{O}_{2}^{-} \cdot \rightarrow \mathrm{O}_{2}+\mathrm{OH}^{-} \\
& \hline \mathrm{H}_{2} \mathrm{O}_{2}+\mathrm{OOH}^{-} \rightarrow \mathrm{O}_{2}+\mathrm{OH}^{-}+\mathrm{H}_{2} \mathrm{O} \\
& \text { 重金属による分解機構 } \\
& \mathrm{Fe}^{2+}+\mathrm{H}_{2} \mathrm{O}_{2} \rightarrow \mathrm{Fe}^{3+}+\mathrm{HO} \cdot+\mathrm{OH}^{-} \\
& \mathrm{Fe}^{3+}+\mathrm{OOH}^{-}+\mathrm{OH}^{-} \rightarrow \mathrm{Fe}^{2+}+\mathrm{O}_{2}^{-} \cdot+\mathrm{H}_{2} \mathrm{O} \\
& \mathrm{HO}^{\cdot}+\mathrm{O}_{2}^{-} \cdot \rightarrow \mathrm{O}_{2}+\mathrm{OH}^{-} \\
& \hline \mathrm{H}_{2} \mathrm{O}_{2}+\mathrm{OOH}^{-} \rightarrow \mathrm{O}_{2}+\mathrm{OH}^{-}+\mathrm{H}_{2} \mathrm{O}
\end{aligned}
$$

図 9 に Fe, Mn，Cu イオンの過酸化水素の分解へ の影響を示す。 $\mathrm{pH}$ が高くなるほど分解が早くなりま すし, Cu イオンは過酸化水素を激しく分解すること
がわかります。

\subsection{DTPA の過酸化水素の安定化効果}

電荷の変わる重金属は，金属の酸化・還元触媒作用 により過酸化水素の分解を促進する。キレート棛の金 属イオンは一般に電荷の高いほうが安定であるので, 金属をキレート化してマスキングすることにより酸化 ・還元触媒作用を押さえることができる。また，金属 の周りにキレート環の立体障壁ができるので，ラジカ ルとの反応を防ぐことができる。

ケイ酸ソーダや $\mathrm{Mg}$ イオン（硫酸マグネシウム）は, 過酸化水素の安定剤として古くから使用実績がある。 また, ケイ酸ソーダは, $\mathrm{pH}$ 緩衝性のあるアルカリ源 としての効能がある。近年, プロセスのクローズド化 によりケイ酸金属塩のスケールトラブルが顕著になり，
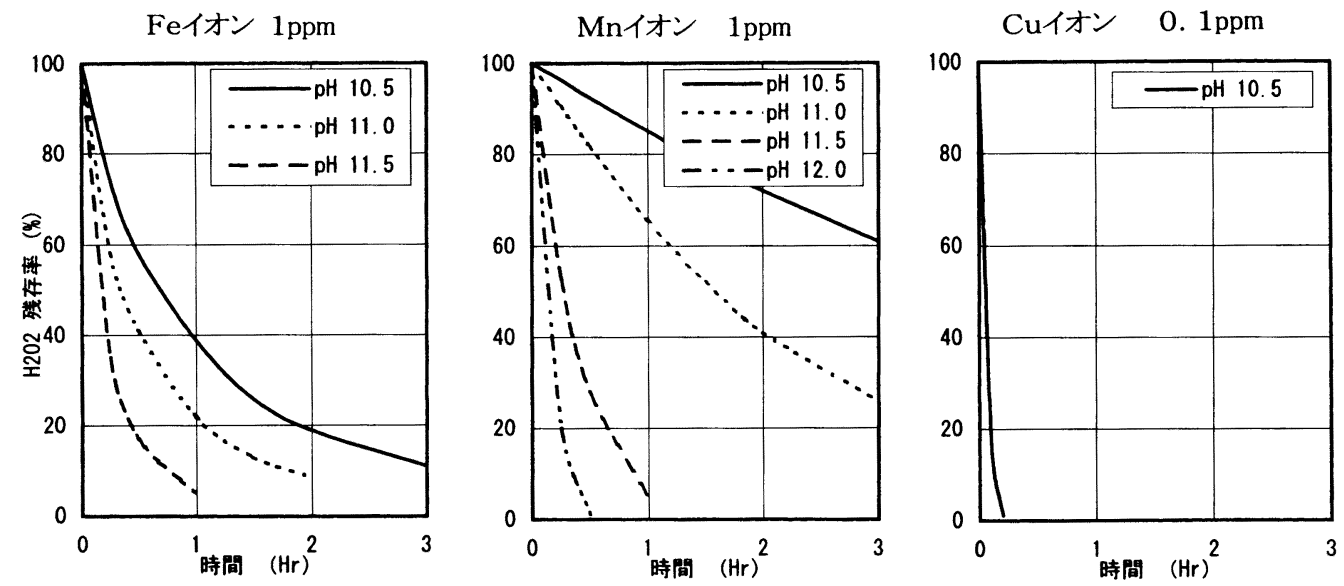

図 9 過酸化水素の分解に及ぼす金属と $\mathrm{pH}$ の影響 ( 1 号ケイ酸ソーダ $/ 0.1 \%, \mathrm{H}_{2} \mathrm{O}_{2}$ 初期濃度 $/ 0.1 \%$, 温度 $/ 80^{\circ} \mathrm{C}$ )

Feイオン $1 \mathrm{ppm}$

$(\mathrm{pH} 11.0)$

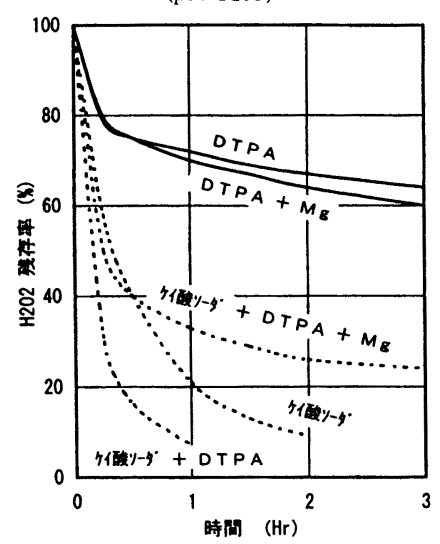

Mnイオン $1 \mathrm{ppm}$

$(\mathrm{pH} 11.5)$

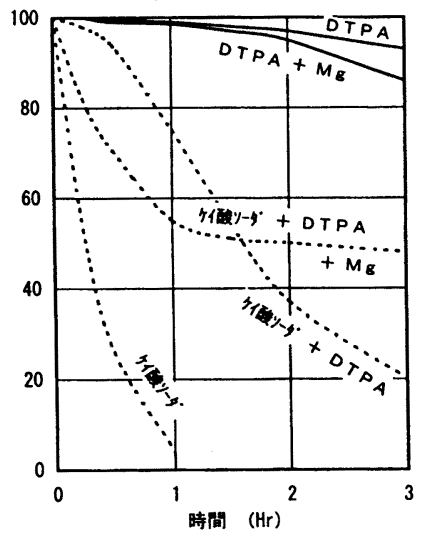

Cuイオン $0.1 \mathrm{ppm}$

$(\mathrm{pH} 11.5)$

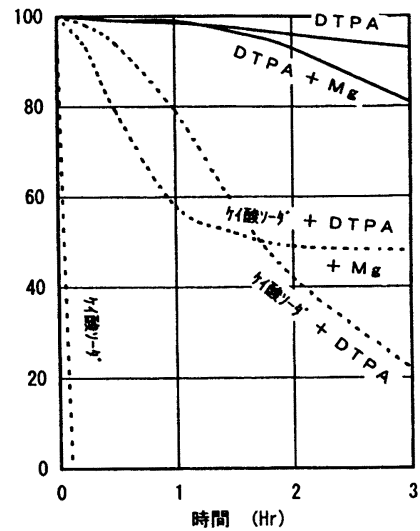

図 10 キレート率の過酸化水素安定化効果 (安定剤の併用効果)

(1 号ケイ酸ソーダ $/ 0.1 \%$, DTPA $4 \mathrm{Na} 40 \%$ 液 $/ 0.015 \%, \mathrm{Mg}$ イオン $/ 1.7 \mathrm{ppm}, \mathrm{H}_{2} \mathrm{O}_{2}$ 初期濃度 $/ 0.1 \%$, 液温 $/ 80^{\circ} \mathrm{C}$ ) 
キレート剂を併用するケースが多くなってきている。

図 10 に金属イオンを添加した液での，キレート剂 の過酸化水素安定化効果を示す。キレート剂は, $\mathrm{Mn}$, $\mathrm{Cu}$ イオンに対しては良い安定化効果を示すが, Fe イ オン存在下では，ケイ酸との併用は分解を促進する結 果が出た。プロセスにより, 過酸化水素の分解を促進 している金属イオンは異なるので，キレート剤とケイ 酸ソーダの使い分けが必要と思われる。

$\mathrm{Fe}$ イオンに対する安定剤の効果は複雑で, 組み合 わせと評価条件により異なった結果の報告がある。図 11 に, 過酸化水素の安定化効果の文献例を示す。

古紙漂白工程では, $\mathrm{CaCO}_{3}$ が懸濁した液で漂白が 行われる場合がある。 $\mathrm{CaCO}_{3}$ 微粉末を $0.1 \%$ 分散さ せた条件で, キレート剂の過酸化水素に対する安定化 効果を測定した結果を表 8 に示します。EDTA， DTPA とも, Mn, Cuイオンに対して安定化効果が ある。

\section{8. 色戻り防止効果}

時間の経過や光の照射によって, 金属イオンとリグ ニンやフェノール誘導体が反応してパルプの色が黄色 化する傾向がある。Y.NI 等の報告では, BCTMP の 光照射による黄色化はパルプ中の Fe イオンの影響が 大きく，パルプ製造工程でDTPA を使用したり，パ ルプシートにDTPA 水溶液をスプレーすることによ り，黄色化を減少させる効果があった（図 12）。

\section{9. ピッチトラブルの防止効果}

木材中の樹脂成分はアルカリ性では溶解しているが, 工程中で $\mathrm{pH}$ 低下すると, 水中の硬度成分と結合して 不溶性のピッチになり製品の品質を低下させる。分散 剂で析出するピッチの粒子を細かくすることにより問 題を解決する方法があるが，キレート剤で硬度成分を マスキングすると硬い樹脂金属塩は生成しないので, より分散効果をあげることができる（表 9）。

\section{0. 生分解性キレート剂の開発}

アメリカ，ヨーロッパのようなアルカリ性土壤では 水の硬度成分が多くて，キレート剤の使用が日本の 5 〜 10 倍 (アメリカ 13 万トン, ヨーロッパ 9 万トン) に及ぶ。また, 河川が長いので水の再利用率も高いた め, EDTAの環境中への蓄積が検出されている。日 本では，まだ河川や湖でのキレート剤の蓄積の事実は ない。EDTA, DTPAの河川水中での代謝分解経路 を図 13 に示す。EDTA は通常の活性污泥法では分解 し難い化合物である。分解菌の探索や活性污泥処理装
置の運転条件の最適化により EDTA は生分解するこ とができるが，一定の馴養期間が必要である。EDTA の活性污泥処理例を図 14 と図 15 に示す。

生分解性キレート剂を合成するには，キレート剂の 分子量を小さくして代謝を容易にする方法と，生物が

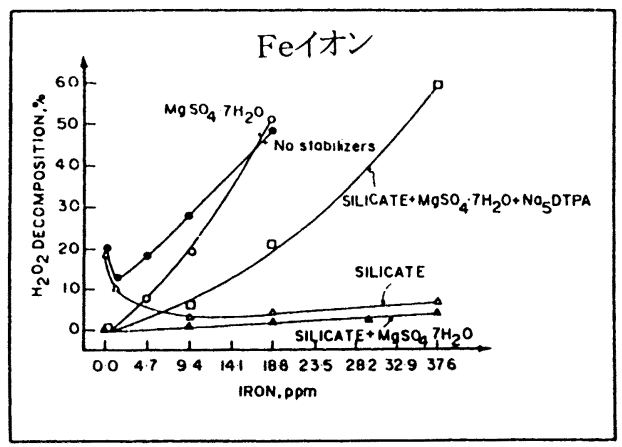

Effect of iron on the decomposition of $0.098 \mathrm{M} \mathrm{H}_{2} \mathrm{O}_{2}$ in the presence of various stabilizers and combinations of stabilizers $\left(\mathrm{Na}_{2} \mathrm{SiO}_{3}, 16.7 \mathrm{~g} / \mathrm{L} ; \mathrm{Na}_{5} \mathrm{DTPA}, 0.34 \mathrm{~g} / \mathrm{L}\right.$; initial $\mathrm{pH}$ $10.8,50^{\circ} \mathrm{C}, 120 \mathrm{~min}$ ).

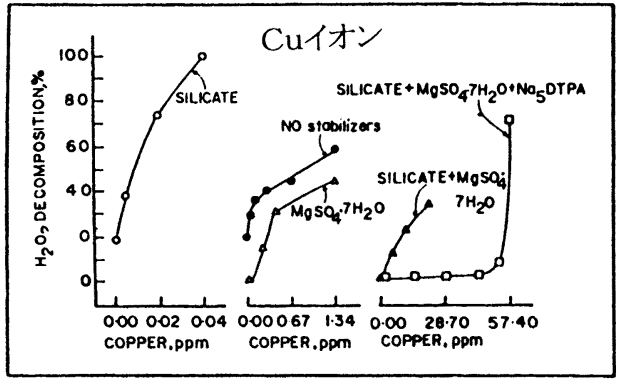

Effect of copper on the decomposition of $0.098 \mathrm{H}_{2} \mathrm{O}_{2}$ in the presence of various stabilizers and combinations of stabilizers $\left(\mathrm{NaSiO}_{3}, 16.7 \mathrm{~g} / \mathrm{L} ; \mathrm{MgSO}_{1} \cdot 7 \mathrm{H}_{2} \mathrm{O}, 0.17 \mathrm{~g} / \mathrm{L}\right.$; NasDTPA, $0.34 \mathrm{~g} / \mathrm{L}$; initial pH $10.8,50^{\circ} \mathrm{C}, 120 \mathrm{~min}$ ).

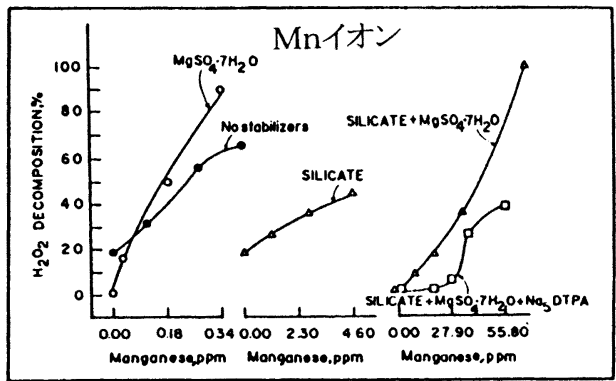

Effect of manganese on the decompositin of 0.098 $\mathrm{M} \mathrm{H}_{2} \mathrm{O}_{2}$ in the presence of various stabilizers and combinations of stabilizers $\left(\mathrm{Na}_{2} \mathrm{SiO}_{3}, 16.7 \mathrm{~g} / \mathrm{L} ; \mathrm{MgSO}_{4} \cdot 7 \mathrm{H}_{2} \mathrm{O}, 0.17\right.$ g/L; NasDTPA, 0.34 g/L; initial pH $10.8,50^{\circ} \mathrm{C}, 120 \mathrm{~min}$ ).

図 11 COLODETTE, J, L., ROTHENBER G, S. and DENCE, C. W. [J. Pulp Paper Sci., 15 (2) : J 45-51（1989）］の過酸化水素安定剂の検討結 果 
表 $8 \mathrm{CaCO}_{3}$ が眯濁した液中の過酸化水素の半減時間 $(\mathrm{Hr})$

(1号ケイ酸ソーダ $/ 0.1 \%$, EDTA $4 \mathrm{Na} 40 \%$ 液/0.015\%, DTPA $5 \mathrm{Na}$ $40 \%$ 液 $/ 0.015 \%$ )

$\left(\mathrm{H}_{2} \mathrm{O}_{2}\right.$ 初期濃度 $/ 0.1 \%$, 液温 $/ 60^{\circ} \mathrm{C}$, 液 $\left.\mathrm{pH} / 11.5\right)$

\begin{tabular}{c|l|c|c|c}
\hline \multicolumn{2}{c|}{} & Fe 1 ppm & Mn 1 ppm & Cu 1 ppm \\
\hline $\mathrm{CaCO}_{3}$ ナシ & ケイ酸ソーダ & 0.56 & 0.96 & 0.16 \\
\hline \multirow{3}{*}{$\mathrm{CaCO}_{3}$ 懸濁 } & ケイ酸ソーダ & 10.0 & 0.60 & 0.10 \\
\cline { 2 - 5 } & ケイ酸ソーダ+EDTA & 2.80 & 1.26 & 0.63 \\
\cline { 2 - 5 } & ケイ酸ソーダ+DTPA & 3.20 & 3.75 & 7.50 \\
\hline
\end{tabular}

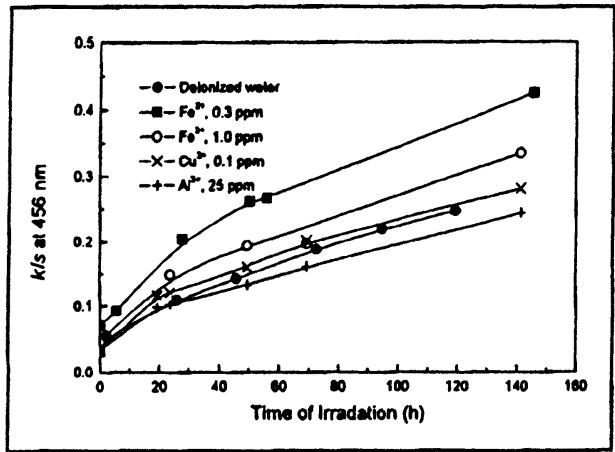

Light-nduced brightness reversion of BCTMP sheets made with solutions containing different metal lons.

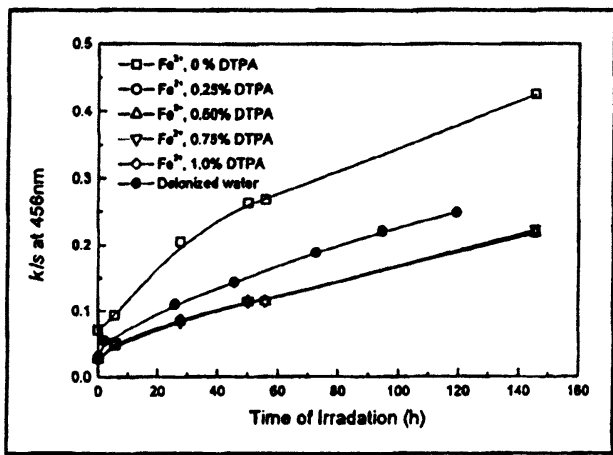

Effect of DTPA spray on the light-induced brightness reversion of BCTMP sheots containing ferrous lons.

図 12 CTMP の光黄色化の防止

[Y. NI, A. GHOSH, J. Pulp Paper Sci. 24 (8) 259 (1998)]

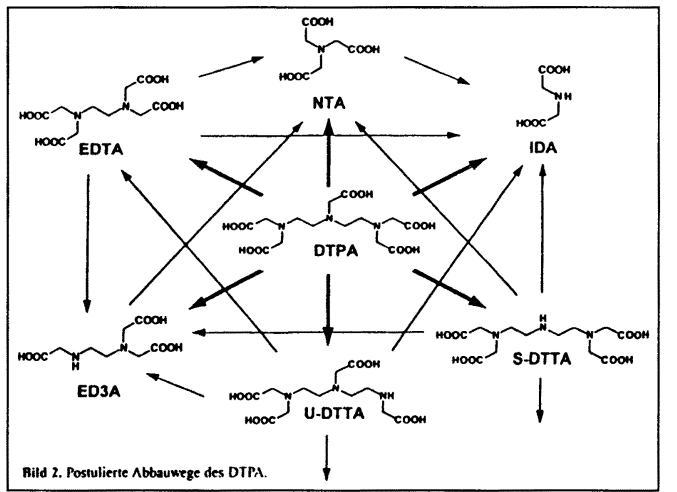

図 13 EDTA，DTPA の代謝経路

[K. Haberer T. A. Ternes, Wasser Aabwasser, 137 (10), 573578 (1996) ]

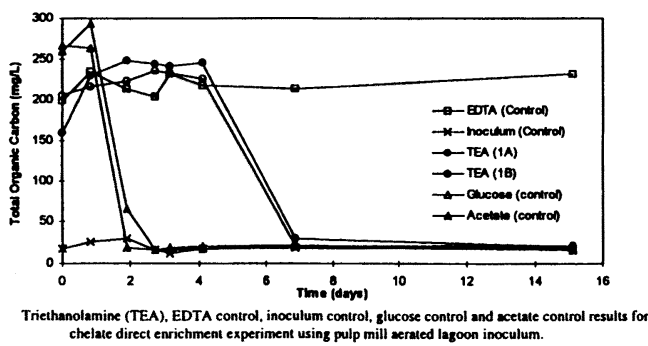

図 14 EDTA の難分解例

[M. L. Hinck J. Ferguson and J. Puhaakka, Wat. Sci. Tech. 135 $(2-3) \cdot 25-31$ (1997) ]

表 9 KP 工程で発生したピッチの分析結果

\begin{tabular}{l|c|c|c|c|c}
\hline \multicolumn{1}{c|}{ 項目 } & 值 & 項目 & 值 & 項目 & 值 \\
\hline 外観 & 黑色 & $\mathrm{Ca}(\%)$ & 12.0 & $\mathrm{Na}(\%)$ & 0.20 \\
\hline 水分 $(\%)$ & 38 & $\mathrm{Mg}(\%)$ & 2.5 & $\mathrm{Fe}(\%)$ & 0.15 \\
\hline 灰分 $(\%)$ & 37 & $\mathrm{Cu}(\%)$ & 0.4 & $\mathrm{Mn}(\%)$ & 0.08 \\
\hline 酸不溶分 $(\%)$ & 8.5 & $\mathrm{Zn}(\%)$ & 0.3 & $\mathrm{~K}(\%)$ & 0.02 \\
\hline
\end{tabular}




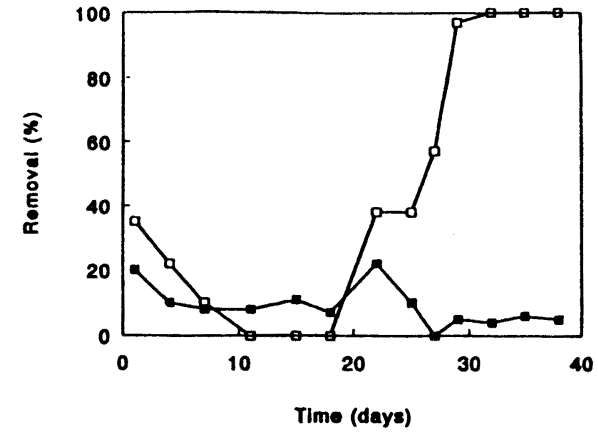

Removal by biodegradation of EDTA $(65 \mathrm{mg} /)$ added to domestic wastewater in SCAS units run at $\mathrm{pH}$ $6.5(\square)$ and $8.5(0)$

図 15 EDTA の分解例

[C.G. van Ginkel Bioresource Technology 59. 151-155 (1997)]

生産する光学活性アミノ酸を原料にする方法がある。 キレート率メーカー各社から生分解性キレート剂が販 売されている。キレート力の強さと生分解性は相反す る傾向にあり，EDTA 並みの製品（キレート力，化 学安定性, 価格) を得るには至っていないが, 用途に よってはEDTAに代替えできる商品ができている。

図 16 に, 生分解性キレート剂のグルタミン酸二酢酸 （キレスト $\mathrm{CMG}-40 ）$ の活性污泥処理による生分解実

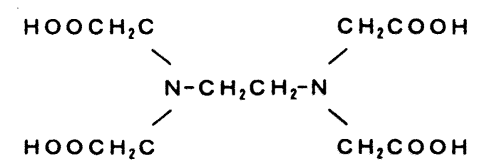

\section{EDTA}

$\mathrm{HOOCH}_{2} \mathrm{C}$<smiles>CCCCCN(CCOO)C(CC(=O)O)C(=O)O</smiles>

アスパラギン酸二酢酸（ASDA）

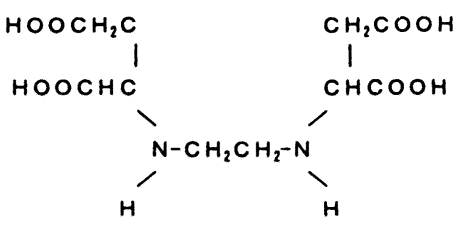

エチレンジアミンジコハク酸（EDDS）

メチルグリシンニ䣫酸（MGDA）

績を示す。

図 17 に主要な生分解性キレート郕の化学式を示す。 いずれも，アミノ酸を原料として合成され，工業的に 生産が行われている化合物である。

図 18 に,グルタミン酸二酢酸の過酸化水素の安定 化効果を示す。従来のキレート殽と同様，鉄イオンに 対しては安定化効果はないものの, $\mathrm{Mn} や \mathrm{Cu}$ イオン に対してはDTPAより優れた安定化効果がある。

グルタミン酸二酢酸（GLDA）<smiles>O=CCN(CC(=O)O)CC(=O)O</smiles>

$\beta$-アラニンニ䣫酸 $(\beta-\mathrm{ADA})$

$\mathrm{HOOCH}_{2} \stackrel{\mathrm{COOCH}}{\mathrm{N}-\mathrm{CHCH}_{2} \mathrm{CH}_{2} \mathrm{COOH}}$

図 17 生分解性キレート剂の構造式（EDTA は比較例として記載） 

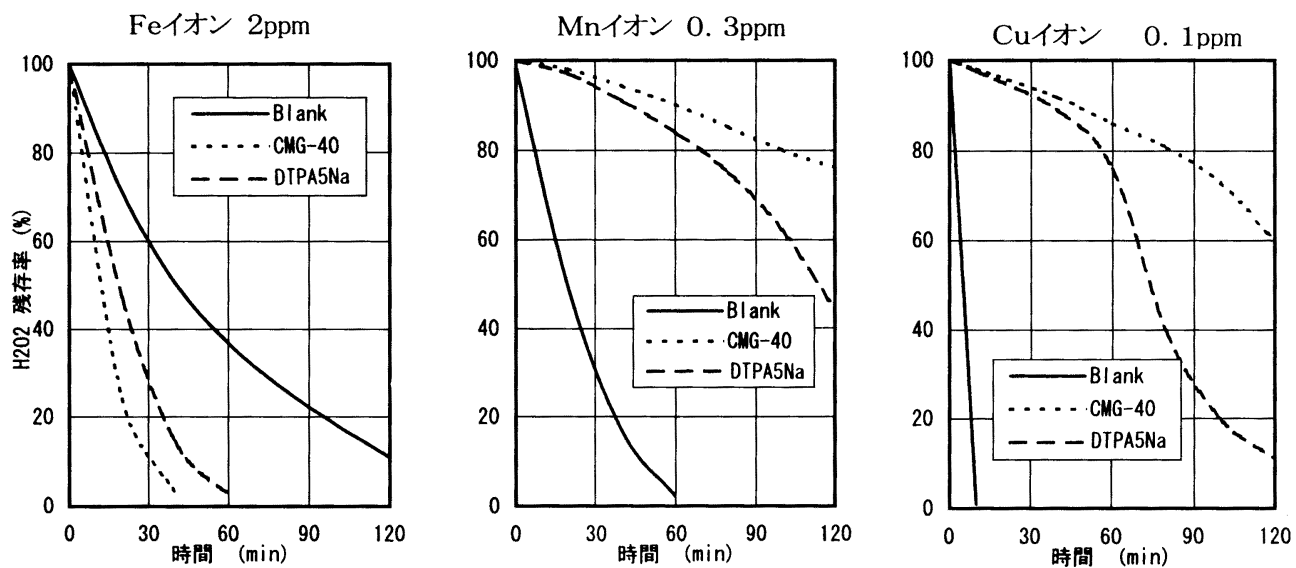

図 18 グルタミン酸二酢酸（キレスト $\mathrm{CMG}^{-40)}$ の過酸化水素安定化効果

(グルタミン酸二酢酸ソーダ $40 \%$ 液 $/ 0.2 \%, \mathrm{DTPA} 4 \mathrm{Na} 40 \%$ 液 $/ 0.2 \%, \mathrm{H}_{2} \mathrm{O}_{2}$ 初期濃度 $/ 0.1 \%$, 液 $\mathrm{pH} / 11.8$, 液温 $/ 92{ }^{\circ} \mathrm{C}$ )

11. おわりに

紙パルプ製造工場は，天然物である原料木材の種類 や品質の違い, 生産する紙の品種の多様性のため, 長 年の歴史と経験より構築された各工場独自のプロセス
がある。金属に起因するトラブルの発現も多種多様で あるが，キレート剤を活用すれば解決できることが多 数ある。本稿により, 紙パルプ工業に携わる方々がキ レート剤に関心を持っていただければ幸いである。 